\title{
Література:
}

1. Концепції розвитку цифрової економіки та суспільства України на 2018-2020 роки та затвердження плану заходів щодо ii реалізації від 17 січня 2018 р. № 67-p. Законодавство України: веб-сайт: URL: https://zakon.rada.gov.ua/laws/show/67-2018-\%D1\%80\#Text.

2. Шевчук І.Б., Депутат Б.Я, Тарасенко О.С Цифровізація та іiі вплив на економіку україни: переваги, виклики, загрози й ризики. Причорноморські економічні студії, 2019. Вип. 47- 2. URL: http://bses.in.ua/journals/2019/47_2_2019/34.pdf.

3. Карчева Г.Т., Смовженко Т.С., Міщенко В.І. Ефективність та конкурентоспроможність банківської системи України / заг. ред. д-ра екон. наук Г.Т. Карчевої. Київ : ДВНЗ «Університет банківської справи», 2016. 276 с.

DOI https://doi.org/10.30525/978-9934-26-045-2-36

\section{PRINCIPLES OF THE IMPLEMENTATION OF LAW ENFORCEMENT FUNCTIONS BY PUBLIC ADMINISTRATION ENTITIES IN UKRAINE}

\author{
Melnyk I. V. \\ Postgraduate Student at the Department of Global Studies, \\ European Integration and National Security Management \\ National Academy for Public Administration under the President of Ukraine \\ Kyiv, Ukraine
}

The law enforcement function of the state is an integral part of ensuring national security, the implementation of which is ensured by several public authorities. The role of the principles of activity of public authorities, in particular within the framework of the implementation of the law enforcement function of the state, acquires special significance due to the need to harmonize the national legislation with international standards, in particular the European Union standards, the reform of the decentralization of power and the reform of the law enforcement agencies themselves, as a result of which a new structure of the administrative-territorial system of the state and the system of law enforcement agencies was formed. In this regard, it is necessary to substantiate the set of principles for the implementation of law enforcement functions by public administration entities. 
The set of principles, on which the law enforcement function of public administration authorities is implemented, can be considered in two meanings:

- law enforcement activities, which are aimed at combating crime and other offenses. These are specialized activities for the legal protection of public relations, which are exclusively carried out by law enforcement authorities.

- activities in which authorized entities ensure the rule of law and the implementation of state policy in this sphere. Such authorities can be institutionally different entities of public administration, which are endowed with appropriate powers in the sphere of ensuring law and order and the implementation of the law enforcement function of the state.

Thus, we can define and substantiate the basic principles of the implementation of the law enforcement function by public administration entities:

1. The principle of the rule of law, which determines the exclusive place of law in society during the implementation of the law enforcement function by public administration entities, that is, state authorities, local selfgovernment authorities and the public. The content and direction of their activities are determined by the highest social values - the rights, freedoms and interests of citizens, but taking into account the effectiveness of the democratic rule of public life - «the rights and freedoms of citizens end where the rights and freedoms of another person begin».

2. The principle of legality is based on the principle of the rule of law. On the basis of this principle, public administration authorities are obliged to fulfill their duties and to strictly comply with the requirements of the relevant regulatory legal acts in order to carry out their law enforcement function effectively and efficiently [2, p. 157]. The implementation of this principle also provides that the relevant public administration authorities for the high-quality and effective implementation of the law enforcement function are empowered to carry out timely control and supervision over the observance of the norms of the current legislation, administrative procedures and rules by all public administration authorities, their officials and all citizens, especially in the conditions of application measures of administrative coercion and means of physical force.

3. The principle of the priority of ensuring the rights and freedoms of man and citizen, which provides that the basis of the activities of public authorities should be based on a «human-centered» ideology during the implementation of law enforcement functions of the state [1]. According to this ideology, not the interests of the state have priority, but the 
comprehensive provision of the rights and legitimate interests of citizens in the sphere of protecting public order and combating crime. Such safe conditions include: development and implementation of state policy in the sphere of security and protection of human and civil rights (in the law enforcement aspect); ensuring an appropriate level of law and order in the state and society; increasing the level of protection of citizens from unlawful encroachments; raising public awareness of significant threats to the rule of law and the scale of organized crime [4, p. 44].

4. The principle of equality of citizens before the law does not provide privileges and restrictions based on race, political and religious beliefs, social origin, etc. [3, p. 71-72]. That is, all citizens have the same rights and obligations in the sphere of administrative and legal relations arising in public life, in particular in the law enforcement sphere. Relevant executive authorities should develop a system of effective measures to combat this discriminatory phenomenon, which occurs in almost all countries of the world, for the high-quality and effective implementation of the law enforcement function.

5. The principle of the prohibition of abuse of power, that is, abuse of official authority (their dishonest use or use with a distorted interpretation of the purpose, for which the authority is granted, is used for their own interest) [6, p. 233-234]. Torture and cruel treatment of people, who are in law enforcement authorities, in order to obtain the necessary operational information is one of the most widespread abuse of power in public authorities exercising law enforcement functions.

6. The principle of competence and professionalism. The concept of «professionalism» is defined as a qualitative characteristic of the subject of activity, which is a representative of a particular profession and is determined by the degree of mastery of modern means of solving professional problems [5]. The substantive component of state policy in the law enforcement sphere depends on the level of professionalism of employees of public authorities directly (the degree of identification of the main problems in the implementation of law enforcement functions and the completeness of measures to eliminate them) [4, p. 45].

7. The principle of transparency and openness, which provides that the public can take part in the formation of state policy in the law enforcement sphere by discussing draft regulatory legal acts. This opportunity determines the presence of an active civic position of the population in resolving issues at national, regional and local levels.

8. The principle of mutual responsibility of the state and the individual provides that the state and the citizen are bound by the institution of 
citizenship by mutual rights and obligations. [3, p. 72]. This interrelation demonstrates that a person, who violates the requirements of the law, is necessarily brought to justice, and the state is obliged to compensate for the material and moral damage caused to the person by illegal actions of state authorities and their officials [4, p. 45].

9. The principle of constant interaction and communication of public administration entities (Community Policing), primarily law enforcement authorities, in the sphere of law enforcement and citizens, territorial communities and public organizations on the basis of partnership and interaction. The implementation of this principle should be aimed at satisfying the common interest in the sphere of ensuring law and order in the state as well as provides for the need to establish a dialogue between the population and authorities, build cooperation to protect and enhance security at the local level.

Thus, we can generalize that the effective implementation of the law enforcement function of the state, as a specific and clearly regulated type of activity in the sphere of ensuring and maintaining law and order in the state, can be achieved as a result of the observance of these principles by all subjects of public administration at all management levels.

\section{References:}

1. Averianov V.B. Approval of the Principle of the Rule of Law in the New Doctrine of Ukrainian Administrative Law. Bulletin of the Ministry of Justice of Ukraine. 2006. No. 11 (61). P. 57-63.

2. Administrative Activity of Militia: Textbook / under the general editorship of the Academician of the Academy of Legal Sciences of Ukraine, Professor O.M. Bandurka. Kharkiv: Publishing House of the National University of Internal Affairs, 2004. 448 p.

3. Administrative Law of Ukraine. General Part. Academic Course: Textbook / under the general editorship of the Academician of the National Academy of Legal Sciences of Ukraine O.M. Bandurka. Kharkiv: Zolota mylia, 2011. $584 \mathrm{p}$.

4. Bezpalova O.I. Principles of Implementation of the Law Enforcement Function of the State: Administrative and Legal Aspect. Journal of Eastern European Law. 2013. No. 1. P. 40-46.

5. Kovalenko S.V. The Essence and Specifics of the Phenomenon of Professionalism. Bulletin of the Luhansk State University of Internal Affairs. 2007. No. 1. P. 194-198. 
6. Melnyk R.S. Administrative Law System of Ukraine: Monograph. Kharkiv: Publishing House of the Kharkiv National University of Internal Affairs, 2010. 389 p.

DOI https://doi.org/10.30525/978-9934-26-045-2-37

\title{
FORESIGHT THE COUNTER SABOTAGE CAPABILITIES OF THE CRITICAL INFRUSTRUCTURE PROTECTION UNIT
}

\author{
Sukonko S. M. \\ Doctor of Philosophy in State Security, \\ Associate Professor at the Department of Tactical and Special Training \\ National Academy of the National Guard of Ukraine
}

Chepel M. O.

Doctor of Philosophy in State Security, Senior Instructor at the Department of Social Sciences and Humanities National Academy of the National Guard of Ukraine

\author{
Kolianda V. V. \\ Doctor of Philosophy in State Security, \\ Associate Professor at the Department of Tactic \\ National Academy of the National Guard of Ukraine \\ Kharkiv, Ukraine
}

One of the main directions of public administration in the field of state security is the assessment of counter sabotage at critical infrastructure, and this confirms the necessity in the foresight the counter sabotage capabilities of the critical infrastructure protection unit.

A significant contribution to the theory of protection of critical infrastructure has been made in the works of domestic and foreign scientists: Kirichenko [1, p. 165], Grynenko [2, p. 23-25], Stepanov [3, p. 97], Leus [4, p. 46-49], Radaev [5, p. 28-32], Zenov [6, p. 23-32], Borovskyi [7, p. 235-243], Wadoud [8, p. 831-839].

Today, there are a number of new threats to the critical infrastructure, such as the detonation of life support facilities outside these facilities, the destruction of vulnerable technology systems by the small-size unmanned 